\title{
PUBLIC SEGTOR MANAGERS HANDLING ACCOUNTING DATA: A UK FRAMEWORK VALIDATED IN SPAIN
}

\author{
Derek E. Purdy and Susana Gago*
}

\section{INTRODUCTION}

What individuals think and do when they come into contact with financial management accounting data and the associated systems is of widespread interest. This ranges from accountants and data providers in organizations to the various perspectives of researchers in the academic community (Purdy, 1991a, 1993a, 1993b and 1995). The outcomes and psychology of these personal interactions are deemed important.

One framework about such interactions dealt with an individual in receipt of financial management accounting data in a UK teaching hospital. This Framework of Issues was considered to be basic and common to both individuals and organizations. The Issues had been generally validated through conversations with the managers of ward units and consequently considered to arise with any such individuals who worked in similar hierarchical organizations (Purdy, 1993a). These conversations also indicated that extensions could be made to the Framework Issues and this paper incorporates these.

In the recent past there have been changes in the public sectors of the more market-orientated and money-conscious economies in the world. Generally the changes have involved accounting and sought to conserve cash or reduce cash expenditures. At the end of the last century, countries in the European Union, particularly those who wanted to enter the Euro-zone, tightened control of public sector expenditures. A Euro-zone country's national budget deficit was not to exceed the $3 \%$ convergence criteria agreed in the Maastricht Treaty. In Spain public sector resources were reduced to achieve this.

A group of Spanish researchers wanted to understand how public sector managers were affected by such systems and how they used the accounting data supplied. Since they worked in Galicia they carried out field studies with the managers of seven Galician Business Schools. The results showed that five

* The authors are respectively from the University of Reading and Carlos III University of Madrid University of Santiago de Compostela. The paper was written with the collaboration of América Álvarez, Fernando Barros and Raúl Canay from the University of Santiago de Compostela and Maria José Domínguez from the Xunta de Galicia.

Address for correspondence: Derek E. Purdy, Department of Management, University of Reading, PO Box 218, Reading RG6 6AA, UK.

e-mail: D.E.Purdy@reading.ac.uk 
of the six managers with accounting education did not use accounting data for their decision-making (Gago et al., 1997a and 1997b).

The Spanish researchers tried to generate understandings of their material, found it hard and changed direction when they became aware of Purdy's UK Framework (Purdy, 1993a). This Framework seemed to be appropriate for the centralised Spanish situation and thus a British-Spanish group of researchers decided to apply it. This paper describes that process.

This paper explains the Purdy Framework (1993a) then discusses some of its notions before suggesting a research agenda. Those Original Framework Issues are extended through the previous findings and some of the original issues made finer and re-ordered. The Framework is revised for the Spanish situation and this provides nineteen issues which are compared with the material collected by the Spanish group. The findings are discussed and conclusions drawn.

\section{THE PURDY FRAMEWORK (1993a)}

The stimulus for the Framework arose from the Purdy's interests in the effects of financial management accounting data upon individuals and the associated organizational processes. Between 1988 and 1990 Purdy started a study consisting of two conversations held 18 months apart with Managers of a 4 Ward Unit in a NHS teaching hospital. At that time, the situation in the NHS was direct government control, cash limits, new systems of management and new financial management accounting data. The objective of the study was to consider how the individual recipients of this data, the Ward Unit Managers, would deal with the situation and to ascertain their views (Purdy, 1993a).

Purdy's approach suggested that the position of the Ward Unit Manager and the ability of the manager to influence affairs would be a function of personal and organizational factors. As it was an individual approach, Purdy expected differences between the managers, but felt that there would be certain issues in common. Purdy anticipated the Eight Issues that are in Table 1.

Purdy (1993a) mentioned several further matters when he proposed these issues. A simple notion of control was introduced, which required a measurable objective, predictions about the objective and the opportunity to undertake intervening action (Otley and Berry, 1980). This was viewed as a representation of the obviously complex control mechanism of an individual. The paper's approach was through psychology and in particular the psychology of personal constructs, which anticipated that each individual would have their alternative constructions of events (Kelly, 1955).

The paper observed that an individual recipient's ability to use data and to influence events is associated with the individual's facility to understand the 


\section{Table 1}

\section{The Original Framework of Eight UK Issues}

1. The budget is imposed without the manager's influence.

2. This budget is more related to cash limits than to the Unit's work.

3. The financial management accounting data received is from a source hierarchically above the manager in the Hospital, and it is based upon a custodial accounting system for financial accounting.

4. The accounting data is inadequate and untimely for the manager. The accounting system does little to alter this situation and is evolving to deal with cash-restricted budgets.

5. The manager has little appreciation of budgets, and associated matters, and has not been trained in these areas.

6. The manager does not have financial awareness and does not understand the data, and so consequently he has only a limited ability to use it.

7. The ability of a manager to control the expenditures from the cash-restricted budget will depend upon the extent to which he can control the activities of the area, and the extent to which the expenditures on these activities coincide with the budget.

8. The manager considers that specific knowledge about the budget should not go any further, because, for example, the manager is responsible for the budget.

data, its context, its usefulness, the possibilities of using it, its timeliness and the type of data. Previous work with NHS managers had found that they varied in their ability to understand financial management accounting data, this affected their ability to handle data and might alter with training and did alter with learning on the job (Purdy, 1991b). Also, previously the NHS had produced stewardship-based data, rather than budget-type data (Purdy, 1993a).

Budgeting is a complex affair, amongst other things, arising from the relationships of a budget with other parts of an organization. The budget's use is associated with the manager's personality and pattern of leadership (Argyris, 1952; and Hopwood, 1973). As a consequence of all of these factors it was assumed that if both the Ward Unit Managers and the accounting data were new, the Ward Unit Managers would not be used to dealing with the data and so be naïve (Purdy, 1993a).

The Eight Issues were not considered to be the only issues which could arise, but were the ones which were both basic and common to individuals and organizations in this context. They provided a general framework for the analysis of the conversations, and a means to amend or abandon this framework (Purdy, 1993a).

The Eight Issues were inferred from an anticipated and generalised context of public sector events, and was without knowledge of the hospital. Purdy assumed, that a hospital would follow its hierarchy and hand down a budget to managers, that the Ward Unit Managers would come from within the 
NHS, and that they would not have been used to receiving and handling financial management accounting data. Purdy did not know the position of the Ward Unit Managers but from these assumptions, considered they would be naïve in relation to financial management accounting data (Purdy, 1993a).

The naïve position also provided a minimum basis from which to work. Purdy anticipated that a naïve recipient of data would encounter difficulties in handling it and might choose to ignore it. He accepted that a naïve recipient of data could move from this naïve position with any combination of formal training, explanations and use of that data (Purdy, 1993a).

After the conversations, Purdy observed that the Framework Issues had arisen in these conversations and this suggested that the Framework had been validated. The Framework appeared to have dealt with the dynamic situations of individuals, allowing for the variability among individuals in what might appear to be similar situations. Other matters arose and Purdy highlighted notions of remuneration, performance and success that were likely to be important in further work (Purdy, 1993a). Also, Bourn considered most of the Eight Issues related to the approaches to devolution taken by the management of Australian Universities (Bourn, 1991). This added evidence to Purdy's view that, the Framework was applicable to other parts of the NHS, the public sector and other imposed, cash-restricted situations (Purdy, 1993a).

\section{OBSERVATIONS ON THE PURDY FRAMEWORK (1993a)}

Purdy produced a Framework which anticipated Eight Issues. Also he anticipated that these Issues could be amended and used in other contexts (Purdy, 1993a). Before any amendments we comment on the Framework to clarify matters and the potential for research.

\section{Its Function}

The Framework was an anticipation of a number of dynamic issues that were considered to be the concern of hospital managers in 1988, and would help to identify how the individual recipients of financial management accounting data deal with the situation. In one sense the Framework could be considered as a description of the state of affairs at a point, however, the Framework is both a description and a number of anticipations. These anticipations in the Framework of Issues are similar to hypotheses. They could be considered a series of hypotheses, which Purdy set out to confirm. His paper, however, did not treat these as hypotheses, the methodology indicates that this was not the case and the findings indicated only that the Framework had been validated (Purdy, 1993a).

The situation of an individual's receipt of data is not as straightforward as trying to produce hypotheses, where the observed object is expected to remain 
constant whilst being observed. This is because any one issue in a situation with an individual is capable of altering simultaneously with any combination of the other issues. The statements in the Framework were not drawn up to represent hypotheses but as personal constructs about eight areas. Applying the notions of personal constructs (Kelly, 1955), the personal constructs of these Eight Issues are areas capable of application to an individual in a particular way at one point, which can alter to apply in another way because of an event at a point which immediately follows.

The Framework is not trying to analyse the various types of decisions, the types of decision contexts and then relate accounting data use to these. It also does not deal with the many individual decisions taken by a manager during work. Purdy has shown that in order to be able to use accounting data, in a conventional way, individuals require financial management accounting constructs (Purdy, 1991b). That paper indicates there are other notions about managers relevant to the use of accounting data alongside those of the Framework. It is clear that the whole personal situation relating to the use of accounting data is more complex and more subtle than is contained in Purdy (1991b and 1993a) and this paper.

\section{Learning and a Continuum}

As Purdy indicated, an individual is capable of learning about financial management accounting data (Purdy 1993a), and in this way the individual's personal constructs change (Purdy, 1991b). In view of this, it is possible to consider the Framework as a series of issues, which are capable of being used with an individual, who is at any stage of ability to handle the financial management accounting data provided, and whose stages can alter. An individual could be naïve but becomes educated with regard to the data. These conditions can be represented by a Continuum of the varying stages of data handling, which is shown in Figure 1.

This Framework of Issues can be suitably adapted to any context and applied to the whole range of individuals and groups handling the data, from the naïve to the educated. This also can be represented as a Continuum as shown in Figure 1. A manager who had a good grasp of accounting concepts and could handle the data in a purposeful manner would be in the educated part of the continuum. The Issues most related to the Continuum are 5, 6 (to

\section{Figure 1}

A Continuum for Handling Data with Individuals and Groups

Naïve in Use Less Naïve in Use $\begin{aligned} & \text { Less Educated } \\ & \text { in Use }\end{aligned}$


become later 5, 6, 7, 8, 9 and 10), 7, and possibly 8 and 9 (to become later 11 , 12 and 13$)$.

\section{Its Setting}

The Original Framework was pitched at the naïve part of the Continuum as the Ward Unit Managers were thought to be at this particular stage with respect to data handling. Purdy was not really correct about this, as on his first visit the managers had been receiving a monthly computer printout of data from the central accounting system for two and a half years. However, on his second visit, one of the original managers had left and had been replaced by a person who had been working for three and half months. This manager admitted not understanding the data and was more naïve about data than the other managers on the first visit (1993a). At the study's end one manager was close to the naïve part of the group Continuum, whilst the other three were located in the educated part.

\section{Researching Individuals}

Of course the particular organizational context in which any empirical studies are conducted will vary as will the situation with individuals. The more that the researcher knows about a general situation in advance of a study, the more towards the actual situation the anticipated outcomes of the Framework can be adjusted beforehand.

The finer or more sensitive the distinctions of Issues in the Framework can be made, so the finer or more sensitive the views of recipients can be compared with it. The creation of finer distinctions makes it easier to handle the individual differences coming from the different contexts and the individual's experiences. This should make it easier to forecast the positions of managers in an organization or their individual positions in relation to the Continuum.

\section{Its Sufficiency}

Purdy's contention is that the Framework helps to identify how the individual recipients of financial management accounting data deal with the situation. It does not contend that everyone will be in the same situation. Are the number and type of Issues in the Purdy Framework sufficient for it to become a general research instrument for examining the use of data by recipients? This will be revisited later.

At the outset, Purdy made it clear that the Framework was unlikely to have included every issue. Indeed, Purdy indicated that a revised framework might include notions of remuneration, performance and success. The paper indicated that funds were allocated according to historic precedent rather than work, and that in at least two Units the managers were involved in 
producing their own budgets to help keep the cash limit (Purdy, 1993a). These five Issues should also be added to the Framework.

Purdy felt the Framework could be applied to other parts of the NHS, to the public sector and to other imposed cash-restricted situations (Purdy, 1993a). All of these matters invited further research into the position of data recipients in a variety of contexts. The Framework is revised here for use with Managers in Galician Universities.

\section{AMENDMENTS TO THE FRAMEWORK}

\section{$U K$}

Purdy's (1993a) findings were re-considered and the Issues added (with numbers) about budget allocations (3), own budgets (13), remuneration (15), performance (16) and success (17).

3 The cash limit is allocated to the manager more in relation to historic precedent than anticipated work.

13 The manager will construct her own budget as a plan to keep within the cash limit imposed.

15 The manager's remuneration is an important aspect of her desire to carry out the job.

16 The manager does not want the remuneration to be related to performance measures, because she has little or no control over setting these measures and of being able to influence these.

17 The manager considers her notions of success are important to both her ability to control affairs and her consequent self-confidence in relation to the job.

Also, from the Original Framework, Issue 4 was made finer/simplified into four parts, and Issue 5 into two parts, then renumbered. (In fact this simplification was done when the Spanish material was analysed because some parts were absent, but for reading this paper and subsequent UK work it is easier for us to amend it here rather than later.)

5 The accounting data is inadequate.

6 The accounting data is not timely.

7 The accounting system does little to alter the inadequacy and timeliness of data.

8 The accounting system is altering to deal with cash-restricted budgets.

9 The manager has little appreciation of budgets, and associated matters.

10 The manager considers that she has NOT been trained in these areas.

The Revised Framework of 17 UK Issues is in Table 2. 
Table 2

The Revised Framework of Seventeen UK Issues

1. The budget is imposed without the manager's influence.

2. This budget is more related to cash limits than to the manager's work.

3. The cash limit is allocated to the manager more in relation to historic precedent than anticipated work.

4. The financial management accounting data received is from a source which is hierarchically above the manager, and it is based upon a custodial accounting system for financial accounting.

5. The accounting data is inadequate.

6. The accounting data is not timely.

7. The accounting system does little to alter the inadequacy and timeliness of data.

8. The accounting system is altering to deal with cash-restricted budgets.

9. The manager has little appreciation of budgets, and associated matters.

10. The manager considers that she has NOT been trained in these areas.

11. The manager does not have financial awareness, does not understand the data and consequently has only a limited ability to use it.

12. The ability of the manager to control the expenditures from the cash-restricted budget will depend upon the extent to which she can control the activities of the area, and the extent to which the expenditures on these activities coincide with the budget.

13. The manager will construct her own budget as a plan to keep within the cash limit imposed.

14. The manager considers that specific knowledge about the budget should not go any further, because, for example, the manager is responsible for the budget.

15. The manager's remuneration is an important aspect of her desire to carry out the job.

16. The manager does not want the remuneration to be related to performance measures, because she has little or no control over setting these measures and of being able to influence these.

17. The manager considers her notions of success are important for both her ability to control affairs and her consequent self-confidence in relation to the job.

\section{Galician Business School Managers}

Table 2, the Revised Framework of 17 UK Issues was examined for its suitability with material that had been discussed before the field studies. (Table 2 was translated into Spanish. It was discussed mainly in Spanish, one amendment was proposed and two additional issues were translated into English for the Extended Framework.)

The general approach was considered suitable for Galician universities, because of the anticipated hierarchical situation, where a Rector has overall responsibility for a university. It was anticipated that the Rector received a cash limited budget from the Galician Education Department and in turn provided a cash limited budget to the Business School Manager (henceforth Manager) to work with. It was noted that, because the Manager had been elected by 
academics, administrative staff and students, the Manager might consider these political contacts as important and have less consideration for the budget.

Before the interviews the Managers' backgrounds were generally unknown to the Spanish group. At that time the group considered Managers came from within the Business School and would have been used to receiving and handling data such as a budget. The previous experiences and training in handling financial management accounting data were anticipated to vary with each Manager. It was assumed that a Manager would be naïve about handling data, but the Manager could become less naïve through interaction and explanations about the data.

The Issues of the Framework were considered and further amendments were made to it. University salaries were modest and on becoming Manager there was a small increase. It was unlikely that remuneration was important to the Manager. Issue 15 was amended.

15 The Manager's remuneration is not an important aspect of her desire to carry out the job.

A Manager would have contacts outside of the School accessing opportunities for work with business organizations and public authorities. Issue 18 was added.

18 The contacts which a manager makes are an important aspect of her desire to carry out the job.

The position of Manager carries social prestige inside and outside the School. Issue 19 was added.

19 The social prestige accompanying a manager is an important aspect of her desire to carry out the job.

The Extended Framework of 19 Spanish Issues is in Table 3. The italics in Table 3 are the amended issues to Table 2 .

\section{FIELD STUDIES}

\section{Background}

Galicia has eight Business Schools in the Universities of Santiago de Compostela, A Coruna and Vigo. There are two types of School. Facultades offer a theoretical background as a support for management decision making and after four years a student receives a Licenciado. Escuelas emphasise theory with in-company training and after three years a student receives a Diplomado. Seven Managers were interviewed. The organizations are called Business Schools for confidentiality, but must not be confused with the same words used in an English or American context. 
Table 3

The Extended Framework of Nineteen Spanish Issues

1. The budget is imposed without the manager's influence.

2. This budget is more related to cash limits than to the manager's work.

3. The cash limit is allocated to the manager more in relation to historic precedent than anticipated work.

4. The financial management accounting data received is from a source which is hierarchically above the manager, and it is based upon a custodial accounting system for financial accounting.

5. The accounting data is inadequate.

6. The accounting data is not timely.

7. The accounting system does little to alter the inadequacy and timeliness of data.

8. The accounting system is altering to deal with cash-restricted budgets.

9. The manager has little appreciation of budgets, and associated matters.

10. The manager considers that she has NOT been trained in these areas.

11. The manager does not have financial awareness, does not understand the data and consequently has only a limited ability to use it.

12. The ability of the manager to control the expenditures from the cash-restricted budget will depend upon the extent to which she can control the activities of the area, and the extent to which the expenditures on these activities coincide with the budget.

13. The manager will construct her own budget as a plan to keep within the cash limit imposed.

14. The manager considers that specific knowledge about the budget should not go any further, because, for example, the manager is responsible for the budget.

15. The manager's remuneration is not an important aspect of her desire to carry out the job.

16. The manager does not want the remuneration to be related to performance measures, because she has little or no control over setting these measures and of being able to influence these.

17. The manager considers her notions of success are important for both, her ability to control affairs and her consequent self-confidence in relation to the job.

18. The contacts which a manager makes are an important aspect of her desire to carry out the job.

19. The social prestige accompanying the manager is an important aspect of her desire to carry out the job.

\section{Methodology-Interviews}

Almost every interaction has been in Spanish to produce this interview material. The original ideas, discussions, questions for the interviews, the interviews, the resulting summaries and discussions of interview summaries were in Spanish. All interview summaries were translated into English for discussion and analysis in both languages.

The Spanish group had considered the matters they wanted an interview to cover and hoped that interviewees would naturally provide material about their own concerns. These matters were in a schedule of eighty nine questions covering the following eight areas. 
1. Character of the Business School and students.

2. Background of the interviewee.

3. Planning, the role of accounting information and its impact.

4. Organizational management and function.

5. Organizational values and influence.

6. External agents.

7. Processes and controls.

8. Quality and innovation.

The Spanish group wanted each Manager's views about the role of both the financial management information provided and the accounting systems that related to the Manager's activities. In autumn 1996 eight Managers were telephoned, told about the group's research, namely the Manager's views about financial management, and its desire to interview them. Seven agreed. Four Managers were interviewed by two group members, three were interviewed by one group member and all interviews were completed by January 1997 with an average time of two hours.

The interview protocol dealt with its purpose, scope and guaranteed confidentiality. It was agreed that no information would be published that could identify a School or Manager in the anticipation that Managers would speak with complete freedom about the real situation in their Schools.

The interviewers encouraged each Manager to talk freely about her circumstances and the matters of concern to her. At each interview group members used the schedule of eighty-nine questions to ensure all of the group's concerns were dealt with, but the schedule was not given to the Manager. Each Manager's views were written down and verbalised simultaneously by a group member, so the Manager could correct the notes taken. Managers were not provided with copies of these notes. All the Managers expressed their perceptions about the information systems in existence, the budgets provided, the role of control and the importance of reducing the expenses under their responsibility.

\section{Methodology-Extended Framework}

The Revised Framework of 17 UK Issues (Table 2) was discussed for its suitability in the context of the matters considered before the interviews. This resulted in three amendments and an Extended Framework of 19 Spanish Issues as in Table 3. These were introduced earlier in the Amendments to the Framework section.

The interview summaries were read for evidence of Issue material that related to the Extended Framework of 19 Spanish Issues. The Spanish Issue material summaries were produced for each Manager. These are not included here because of space restrictions, but abbreviated details of each Manager's context and views appear later in Table 6 and each Managers responses and the Spanish Framework appear later in Table 7. 
The Spanish Issues summaries were compared with the Spanish Issue Extended Framework to ascertain the extent to which the Managers were concerned with the Issues in this Framework and the nature of any other general issues. The outcome of this process was that interviews with four Managers had apparently not covered all Issues, so additional material was provided by phone in October 1997.

\section{Findings}

\section{General}

Details about Schools, the number of students and the years of operating are provided in Table 4 . When some interviews were undertaken the views received were neither clear nor conclusive, because the Manager held a view about one area which appeared to be contradictory to another area. The Managers were aware of this, and we have to accept that the interviewers could only record what they were told, irrespective of the guarantees given and the time and care taken.

\section{Table 4}

Details of Schools

\begin{tabular}{lc|lc}
\hline $\begin{array}{l}\text { Number of } \\
\text { Students }\end{array}$ & $\begin{array}{c}\text { Number of } \\
\text { Business Schools }\end{array}$ & $\begin{array}{l}\text { Years of } \\
\text { Operating }\end{array}$ & $\begin{array}{c}\text { Number of } \\
\text { Business Schools }\end{array}$ \\
\hline $\begin{array}{l}\text { Less than 1,000 } \\
\text { From 1,000 to 2,000 }\end{array}$ & 1 & Less than 8 & 2 \\
From 2,000 to 4,000 & 2 & From 8 to 75 & 3 \\
More than 4,000 & 2 & More than 75 & 2 \\
\hline
\end{tabular}

Four women and three men were interviewed, so the female form is used here. Appointments are renewable after three or four years. Table 5, Managers' Details, shows the number of years experience as Manager and in the University. There is some variability of background amongst these

\section{Table 5}

Details of Managers

\begin{tabular}{lc|lc}
\hline $\begin{array}{l}\text { Years of } \\
\text { Experience as Manager }\end{array}$ & $\begin{array}{c}\text { Number of } \\
\text { Interviewees }\end{array}$ & $\begin{array}{l}\text { Years in } \\
\text { University }\end{array}$ & $\begin{array}{c}\text { Number of } \\
\text { Interviewees }\end{array}$ \\
\hline Less than 2 & 3 & Less than 10 & 1 \\
From 2 to 4 & 2 & From 10 to 20 & 3 \\
More than 4 & 2 & More than 20 & 3 \\
\hline
\end{tabular}


Managers. Three had less than two years experience as a Manager and two had more than four years. One had less than ten years in the university and three had more than twenty.

\section{Management Systems and Accounting}

The close similarities among Schools were because their University's management systems and accounting were based on those of the University of Santiago de Compostela, the University that was responsible for Galician university education until 1990.

The running of a university is regulated by the Ley de Reforma Universitaria (1983). Previously, the Manager took decisions about the School's teaching and research but since the Ley, Departments have decided. The Manager was appointed by the School's Senate, which monitors her job, as does the Rector's team. The general hierarchical organizational structure within which the Manager worked, is represented by Figure 2. The Rector's team established the general policies and provided the resources for the

Figure 2

Diagram Representing a General Hierarchical Organizational Structure

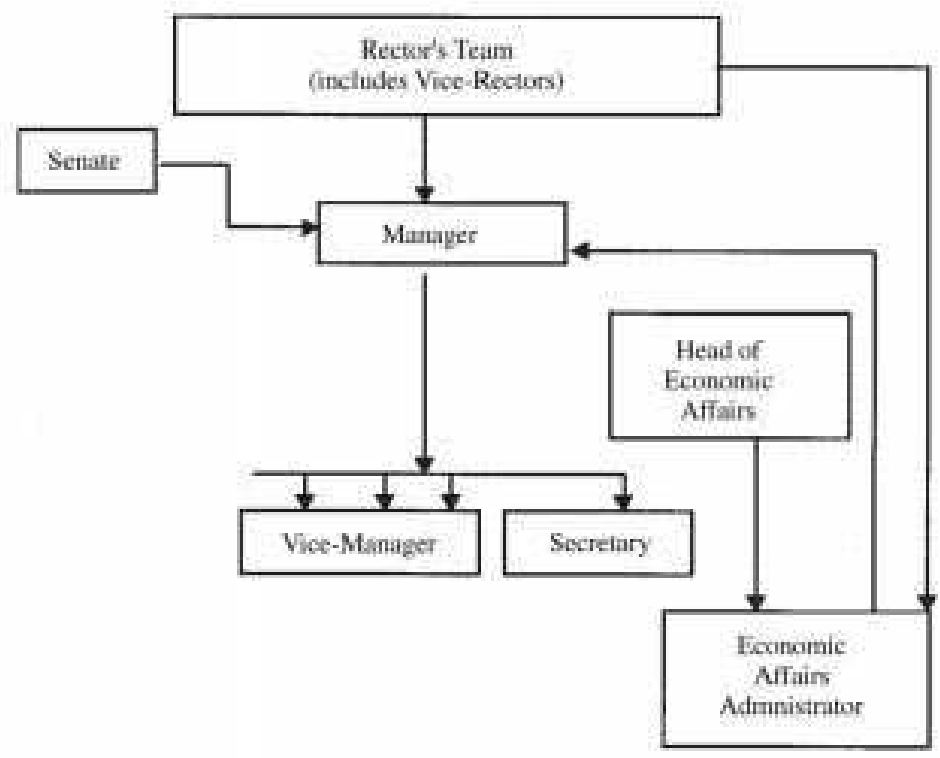


School's development. The School's Senate approved the general guidelines of activity and academic policy, elaborated and approved each curriculum.

A Manager nominates her management team to the Rector. The team's Secretary is responsible for the School's administration. A Manager can have a Vice-Manager to co-ordinate particular areas. A Vice-Rector of Economic Affairs is responsible for the University's accounting system and establishing the School's annual budget, which is incremental - based on the previous year. The School's Economic Affairs Administrator is not a team member, but does administer all economic aspects ensuring that expenditures are drawn against appropriate budget headings and then receiving printed details of these activities. The Manager is responsible for operating with the School's budget economically, efficiently, following the law and norms. The most important items from a School's budget are centrally determined and the Manager has no control over these, whilst the number of items under the control of the Manager varies with the University.

\section{The Managers' Views}

Table 6 contains brief details, to guarantee their anonymity, of each Manager's accounting background, any closely related education, the structure and responsibilities of senior managers, and comments about accounting information.

The outcome of each Manager's interview has been compared with the Extended Framework of 19 Spanish Issues and then summarised as each Manager's responses to the framework as shown in Table 7.

\section{PRELIMINARY DISCUSSION OF MANAGERS' VIEWS OF ISSUES}

\section{Individual Issues}

1. All Managers noted that the budget was imposed and they had no influence upon it, yet Manager 5 noted that she had tried to informally persuade the Rector, and two other managers indicated minor ways to increase their funds.

2. With Issue 2 all Managers noted that the budget was related to cash limits placed on the university rather than the Manager's/School's work.

3. All thought the budget was incremental and based on historical precedent. None knew the origins of the precedent or how it had been calculated.

4. Again all Managers considered that all accounting data originated hierarchically above them from a centralised system operating custodial accounting.

5. With the Issue only Manager 3 agreed that the data was inadequate, but two thought it adequate and four did not express a view. 
6. Only Manager 3 agreed that data was not timely, six did not express a view.

7. Similarly, only Manager 3 agreed that the accounting system did little to alter the inadequacy and timeliness of data, six did not express a view.

8. All agreed that the accounting system altered to deal with cash-restricted budgets. All Managers were aware of cash-restrictions, but from the lack of comments about timeliness, data adequacy and the need for helpful changes, it is assumed that the majority of Managers had no problems, perhaps due to their concern to keep within the cash limit.

9. Manager 3 alone noted she had little appreciation of budgets and associated matters, two Managers thought they did appreciate these and four did not express a view.

10. Manager 5 alone noted she had not been trained in these areas, the other six considered they had. All six had some formal training about accounting, whilst Manager 5 was a lawyer. With so many trained, it is difficult to know why four were not more forthcoming about budgets. Perhaps they appreciated them or perhaps they had nothing to say because they have no direct contact with these.

11. Manager 5 alone noted she did not have financial awareness, does not understand the data and consequently has only a limited ability to use it. Six are financially aware, understand and use data, most come from a business background.

12. All Managers agreed the ability of the manager to control the expenditures from the cash-restricted budget will depend upon the extent to which she can control the activities of the area, and the extent to which the expenditures on these activities coincide with the budget.

13. No Manager constructed her own budget as a plan to keep within the cash limit imposed.

14. Three Managers thought that specific knowledge about the budget should not go any further and three Managers considered that it should.

15. All Managers noted that their remuneration is not an important aspect of the desire to do her job.

16. None mentioned the remuneration to be related to performance measures.

17. Three Managers mentioned that her notions of success are important for both, her ability to control affairs and her consequent self-confidence in the job. Four did not cover this.

18. Five Managers mentioned that the contacts a Manager makes are an important aspect of her desire to carry out the job. Two did not cover this.

19. Three Managers considered that the social prestige accompanying the job is an important aspect of her desire to carry out the job. Four did not cover this. 
Table 6

Each Manager's Context and Views

\begin{tabular}{|c|c|c|c|c|c|c|c|}
\hline Some Findings & Manager 1 & Manager 2 & Manager 3 & Manager 4 & Manager 5 & Manager 6 & Manager 7 \\
\hline $\begin{array}{l}\text { Brief } \\
\text { accounting } \\
\text { background }\end{array}$ & $\begin{array}{l}\text { Trained in } \\
\text { accounting } \\
\text { subjects. }\end{array}$ & $\begin{array}{l}\text { Trained in } \\
\text { accounting } \\
\text { subjects. }\end{array}$ & $\begin{array}{l}\text { Trained in } \\
\text { accounting } \\
\text { subjects. }\end{array}$ & $\begin{array}{l}\text { Trained in } \\
\text { accounting } \\
\text { subjects. }\end{array}$ & $\begin{array}{l}\text { Trained in law } \\
\text { which did not } \\
\text { provide her } \\
\text { with ability to } \\
\text { understand } \\
\text { accounting } \\
\text { information. }\end{array}$ & $\begin{array}{l}\text { Trained in } \\
\text { accounting } \\
\text { subjects. }\end{array}$ & $\begin{array}{l}\text { Trained in } \\
\text { accounting } \\
\text { subjects and } \\
\text { professionally } \\
\text { trained in } \\
\text { business and } \\
\text { public } \\
\text { institutions. }\end{array}$ \\
\hline $\begin{array}{l}\text { Structure and } \\
\text { responsibilit- } \\
\text { ies of the } \\
\text { Senior } \\
\text { Managers }\end{array}$ & $\begin{array}{l}\text { Each Vice- } \\
\text { Manager has } \\
\text { some } \\
\text { autonomy. The } \\
\text { Manager holds } \\
\text { meetings with } \\
\text { the Vice- } \\
\text { Managers of } \\
\text { organization of } \\
\text { teaching, } \\
\text { economic } \\
\text { affairs and } \\
\text { cultural } \\
\text { activities and } \\
\text { the secretary. }\end{array}$ & $\begin{array}{l}\text { The Manager } \\
\text { works through } \\
\text { the three Vice- } \\
\text { Managers of } \\
\text { academic } \\
\text { organization, } \\
\text { economic affairs } \\
\text { and cultural } \\
\text { activities. Each } \\
\text { has some } \\
\text { autonomy, } \\
\text { including the } \\
\text { secretary, but } \\
\text { the Manager } \\
\text { coordinates } \\
\text { these. }\end{array}$ & $\begin{array}{l}\text { Three Vice- } \\
\text { Managers of } \\
\text { academic } \\
\text { affairs, external } \\
\text { relations and } \\
\text { teaching, also } \\
\text { the secretary. } \\
\text { Each has her } \\
\text { own objectives } \\
\text { and autonomy. } \\
\text { They work as a } \\
\text { team. The final } \\
\text { responsibility is } \\
\text { the Manager's. }\end{array}$ & $\begin{array}{l}\text { Four Vice- } \\
\text { Managers: } \\
\text { academic } \\
\text { affairs, external } \\
\text { relationships, } \\
\text { student matters } \\
\text { and economic } \\
\text { affairs, and the } \\
\text { secretary. The } \\
\text { economic } \\
\text { affairs Vice- } \\
\text { Manager is } \\
\text { responsible for } \\
\text { this area. }\end{array}$ & $\begin{array}{l}\text { A Vice- } \\
\text { Manager who } \\
\text { works with } \\
\text { management } \\
\text { systems and a } \\
\text { secretary. }\end{array}$ & $\begin{array}{l}\text { The } \\
\text { Manager } \\
\text { and a } \\
\text { secretary. }\end{array}$ & $\begin{array}{l}\text { This Manager } \\
\text { depends upon the } \\
\text { Manager of } \\
\text { another Business } \\
\text { School for data. }\end{array}$ \\
\hline
\end{tabular}


Table 6 (Continued)

\begin{tabular}{|c|c|c|c|c|c|c|c|}
\hline Some Findings & Manager 1 & Manager 2 & Manager 3 & Manager 4 & Manager 5 & Manager 6 & Manager 7 \\
\hline $\begin{array}{l}\text { Brief } \\
\text { comments } \\
\text { about } \\
\text { accounting } \\
\text { information }\end{array}$ & $\begin{array}{l}\text { The accounting } \\
\text { information is } \\
\text { not used in } \\
\text { decision- } \\
\text { making. }\end{array}$ & $\begin{array}{l}\text { She does not use } \\
\text { budget } \\
\text { information for } \\
\text { decision- } \\
\text { making. }\end{array}$ & $\begin{array}{l}\text { Her control over } \\
\text { the budget is a } \\
\text { legal } \\
\text { responsibility. } \\
\text { She considers } \\
\text { that it would be } \\
\text { possible to } \\
\text { reduce between } \\
60 \%-70 \% \text { of the } \\
\text { costs. There is no } \\
\text { interest in the } \\
\text { accounting } \\
\text { information } \\
\text { systems by } \\
\text { people in the } \\
\text { University. } \\
\text { There is no } \\
\text { accounting data } \\
\text { for real decision- } \\
\text { making. People } \\
\text { do not } \\
\text { understand } \\
\text { accounting } \\
\text { information in } \\
\text { the University. }\end{array}$ & $\begin{array}{l}\text { The budget is } \\
\text { delegated to the } \\
\text { Vice-Manager } \\
\text { who is } \\
\text { responsible for } \\
\text { the economic } \\
\text { affairs area. } \\
\text { The Manager } \\
\text { does not use } \\
\text { accounting } \\
\text { information for } \\
\text { her decision- } \\
\text { making. }\end{array}$ & $\begin{array}{l}\text { The Manager } \\
\text { delegated } \\
\text { economic } \\
\text { affairs to the } \\
\text { Vice-Manager } \\
\text { responsible for } \\
\text { this, and has } \\
\text { absolute } \\
\text { freedom in this } \\
\text { area. }\end{array}$ & $\begin{array}{l}\text { The } \\
\text { information } \\
\text { that she uses } \\
\text { in manage- } \\
\text { ment is only } \\
\text { institutional } \\
\text { information, } \\
\text { not } \\
\text { accounting } \\
\text { information. }\end{array}$ & $\begin{array}{l}\text { Budget } \\
\text { information is } \\
\text { limited and from } \\
\text { the central } \\
\text { system. The } \\
\text { accounting } \\
\text { information } \\
\text { received is } \\
\text { adequate. }\end{array}$ \\
\hline
\end{tabular}


Table 7

Each Manager's Responses and the Extended Framework of Spanish Issues

Manager

1. The budget is imposed without the manager's influence

2. This budget is more related to cash limits than to the manager's work

3. The cash limit is allocated to the manager more in relation to historic precedent than anticipated work

4. The financial management accounting data received is from a source which is hierarchically above the manager, and it is based upon a custodial accounting system for financial accounting

5. The accounting data is inadequate

6. The accounting data is not timely

7. The accounting system does little to alter the inadequacy and timeliness of data

8. The accounting system is altering to deal with cash-restricted budgets

9. The manager has little appreciation of budgets, and associated matters

10. The manager considers that she has NOT been trained in these areas

11. The manager does not have financial awareness, does not understand the data and consequently has only a limited ability to use it

\begin{tabular}{c|c|c|c|c|c|c}
\multicolumn{7}{c}{ Manager } \\
\hline 1 & 2 & 3 & 4 & 5 & 6 & 7 \\
\hline $\mathrm{Y}$ & $\mathrm{Y}$ & $\mathrm{Y}$ & $\mathrm{Y}$ & $\mathrm{Y}$ & $\mathrm{Y}$ & $\mathrm{Y}$ \\
\hline $\mathrm{Y}$ & $\mathrm{Y}$ & $\mathrm{Y}$ & $\mathrm{Y}$ & $\mathrm{Y}$ & $\mathrm{Y}$ & $\mathrm{Y}$ \\
\hline $\mathrm{Y}$ & $\mathrm{Y}$ & $\mathrm{Y}$ & $\mathrm{Y}$ & $\mathrm{Y}$ & $\mathrm{Y}$ & $\mathrm{Y}$ \\
\hline & & & & & & \\
\hline & & $\mathrm{Y}$ & $\mathrm{N}$ & & & $\mathrm{N}$ \\
\hline $\mathrm{Y}$ & $\mathrm{Y}$ & $\mathrm{Y}$ & $\mathrm{Y}$ & $\mathrm{Y}$ & $\mathrm{Y}$ & $\mathrm{Y}$ \\
\hline & & $\mathrm{Y}$ & $\mathrm{N}$ & & & $\mathrm{N}$ \\
\hline $\mathrm{N}$ & $\mathrm{N}$ & $\mathrm{N}$ & $\mathrm{N}$ & $\mathrm{Y}$ & $\mathrm{N}$ & $\mathrm{N}$ \\
\hline & $\mathrm{N}$ & $\mathrm{N}$ & $\mathrm{N}$ & $\mathrm{Y}$ & $\mathrm{N}$ & $\mathrm{N}$ \\
\hline & & & & & & \\
\hline & & & & & \\
\hline
\end{tabular}


Table 7 (Continued)

12. The ability of the manager to control the expenditures from the cash-restricted budget will depend upon the extent to which she can control the activities of the area, and the extent to which the expenditures on these activities coincide with the budget

13. The manager will construct her own budget as a plan to keep within the cash limit imposed

14. The manager considers that specific knowledge about the budget should not go any further, because, for example, the manager is responsible for the budget

15. The manager's remuneration is not an important aspect of her desire to carry out the job

16. The manager does not want the remuneration to be related to performance measures, because she has little or no control over setting these measures and of being able to influence these

17. The manager considers her notions of success are important for both, her ability to control affairs and her consequent self-confidence in relation to the job

18. The contacts which a manager makes are an important aspect of her desire to carry out the job

19. The social prestige accompanying the manager is an important aspect of her desire to carry out the job

\begin{tabular}{c|c|c|c|c|c|c}
\multicolumn{7}{c}{ Manager } \\
\hline 1 & 2 & 3 & 4 & 5 & 6 & 7 \\
\hline $\mathrm{Y}$ & $\mathrm{Y}$ & $\mathrm{Y}$ & $\mathrm{Y}$ & $\mathrm{Y}$ & $\mathrm{Y}$ & $\mathrm{Y}$ \\
\hline $\mathrm{N}$ & $\mathrm{N}$ & $\mathrm{N}$ & $\mathrm{N}$ & $\mathrm{N}$ & $\mathrm{N}$ & $\mathrm{N}$ \\
\hline $\mathrm{Y}$ & $\mathrm{Y}$ & $\mathrm{N}$ & $\mathrm{N}$ & $\mathrm{N}$ & $\mathrm{Y}$ & \\
\hline $\mathrm{Y}$ & $\mathrm{Y}$ & $\mathrm{Y}$ & $\mathrm{Y}$ & $\mathrm{Y}$ & $\mathrm{Y}$ & $\mathrm{Y}$ \\
\hline & & & & & & \\
& & & & & & \\
\hline & $\mathrm{Y}$ & & $\mathrm{Y}$ & $\mathrm{Y}$ & & \\
\hline $\mathrm{Y}$ & $\mathrm{Y}$ & $\mathrm{Y}$ & & & $\mathrm{Y}$ & $\mathrm{Y}$ \\
\hline & & $\mathrm{Y}$ & $\mathrm{Y}$ & $\mathrm{Y}$ & & \\
\hline
\end{tabular}

Notes:

$\mathrm{Y}=$ Yes, $\mathrm{N}=$ No, Blank space $=$ Not mentioned by Manager. 
DISCUSSION OF ISSUES, VIEWS AND THE EXTENDED FRAMEWORK

After examining the Managers' views with individual Issues no Manager fitted the Extended Framework (E Framework) completely. Manager 3 is very close. She has covered more Issues than the other Managers and most of these Issues are in the anticipated direction. The outcomes are discussed further, initially through Manager 3 (M3).

All Managers had similar views about the first four Issues and these agreed with the direction anticipated by the E Framework. These Managers indicated that their University expected them to work with an imposed cashlimit as a budget. Each budget was incremental and based on historical precedent that the Managers did not understand, and the data received related only to receipts and expenditures of budgets.

M3's views followed the anticipated direction of the E Framework with Issues 1 to 4, like all of the other Managers. M3, however, was the only Manager who thought 5 the data received was inadequate, this being in the E Framework's anticipated direction. Only M3 dealt with both 6, timeliness and 7 change in system adequacy and timeliness, and in the anticipated directions. It is suggested that the Issues 5, 6 and 7 are quite sensitive matters for a data user. A sound user would need to be in regular contact with the budgetary situation in order to provide views about the adequacy and timeliness of data and also be aware that an accounting system was prepared to make alterations to these. As M3 was the only one to cover these three Issues it seems that only M3 had a sound working knowledge of the data and systems in this job. This suggests that the six other Managers did not have this sound working knowledge.

Note the Framework considers an individual who is naïve in relation to data received may ignore it. As four of the other Managers have not expressed views about Issues 5, 6 and 7 this could mean that each had no problems and so these Issues were not mentioned. It could also mean they did not know and so the Issues were not mentioned.

Since these are four of the Managers who did not appear to have a sound working knowledge of data and systems it is suggested that they did not know about Issues 5, 6 and 7. This might have arisen because they thought that they did not need to know because others worked with the budgets. A ViceManager worked with Managers 4 and 5, and an Economic Affairs Administrator worked with all Managers.

With 5, for Managers 4 and 7 they thought the data adequate, so not in the anticipated direction of the E Framework. They did not express views about Issues 6 and 7. This is an example of Managers holding contradictory views because they claim the data is adequate 5 , yet they do not have any view about parts of the rest of the system 6 and 7 . If they did handle data then they would have some view about 6 timeliness and 7 change in system adequacy and timeliness. This might have arisen because they thought that they did not need 


\section{Figure 3}

The Relative Arrangement of the Seven Managers (M) on the Continuum for Handling Data

\begin{tabular}{llll}
$\begin{array}{l}\text { M5 } \\
\text { Most Naïve }\end{array}$ & $\begin{array}{l}\text { M4 and M7 } \\
\text { Naïve }\end{array}$ & $\begin{array}{l}\text { M1, M2 and } \\
\text { M6 Less Naïve }\end{array}$ & $\begin{array}{l}\text { M3 } \\
\text { Most } \\
\text { Educated }\end{array}$ \\
\hline Naïve in Use & Less Naïve in Use & $\begin{array}{l}\text { Less Educated } \\
\text { in Use }\end{array}$ & $\begin{array}{l}\text { Educated } \\
\text { in Use }\end{array}$
\end{tabular}

to know. Manager 4 had delegated the budget to the Economic Affairs Administrator, and Manager 7 depended upon the Manager of another School for data, so did not need to know.

The previous four paragraphs have indicated that M3 was at the most educated part of the Continuum for Handling Data relative to the other Managers, as shown in Figure 3. Support for this view comes from M3's accounting information comments in Table 6, that her University had no interest in accounting information systems, no accounting data for real decisions and no people who understand accounting information.

All the Managers noted 8, the system has altered to deal with cash-restricted budgets, and with the emphasis on reducing cash, and was in line with the $\mathrm{E}$ Framework.

The only Manager to cover 9 in the anticipated direction of the $\mathrm{E}$ Framework, that she had little appreciation of budgets and associated matters, was M3. M3's sound working knowledge of the data and systems demonstrates that the budget data received was inappropriate.

Managers 4 and 7 also covered 9, but thought that they did appreciate the budgets. It is not in line with the E Framework. Also, it is another example of Managers holding contradictory views, because the budget was really a cash limit and they claimed to know the difference between a budget and a cash limit. We consider that they do not know this difference.

Managers 4 and 7 views, about 5, the adequacy of data provided, 6 timeliness, 7 change in system adequacy and timeliness, and 9 the appreciation of budgets, indicate that they are at the naïve part of the continuum in relation to those Managers trained in accounting. This is shown in Figure 3. Support for this view comes from Table 6 where Manager 4 does not use the accounting information and has delegated responsibility to a ViceManager and Manager 7 depends upon another Manager for data and notes that the budget information is limited.

Only the law-trained Manager 5, who has no accounting training, covers the training of 10 in the anticipated direction of the E Framework. The other Managers were all trained in accounting. With Issue 11, Manager 5 has no 
financial awareness, no understanding of the data and only limited ability to use it. This is in line with the E Framework. The other Managers consider that they do understand it. In view of this, Manager 5 would appear to be at the most naïve part of the continuum for all of these Managers, and this is shown in Figure 3. Support from Table 6 indicates that all economic affairs have been delegated to a Vice-Manager.

As the Continuum Issues have been dealt with, it is suggested that Managers 1, 2 and 6 appear on the naive part of the Continuum, close to Managers 4 and 7, though they are less naïve than Managers 4 and 7. This is shown in Figure 3.

All Managers appear to have understood Issue 12 that her control of activities will affect her control of expenditures in the direction anticipated. This conforms to the notion of control of the Extended Framework.

No Manager constructed her own budget to keep within the cash limit imposed for Issue 13, and is out of line with the E Framework. Several possible reasons for this finding include, that there was no need for one, that the cash limit would not be spent, that a budget was prepared by someone else. Each Manager had an Economic Affairs Administrator, but there was no indication that these people prepared a budget. This Issue was added after re-considering Purdy's (1993a) UK findings, that Ward Unit Managers had become involved in producing their own budgets. It would appear that for this Issue the Galician Managers are in a different situation to the UK Ward Unit Managers.

With Issue 14 Managers 1, 2 and 6 considered that specific knowledge about the budget should not go further, so these were in the anticipated direction of the Extended Framework. This Issue is one of management style and viewed in the manner of the Framework it suggests single-mindedness through exclusion, thought to be typical of hierarchical organizations, rather than more inclusive styles.

Manager 7, who has no staff, did not mention Issue 14. Managers 3 and 4 shared data with colleagues, and Managers 4 and 5 had delegated budget activities. The last three Managers' styles indicate an inclusive approach in a hierarchical organization. This is contrary to the notion that managers in hierarchical organizatons only act in a manner which seeks to exclude.

It would appear that these styles of handling data with others are not unrelated to a Manager's ability to handle the data received, as shown by the Continuum in Figure 3. It is not a coincidence that Managers 1, 2 and 6 report an exclusive style with Issue 14, and are at the less naive position on the Continuum. Similarly, the naive handling of data by Managers 4 and 5 is related to their delegating or inclusive styles, whilst Manager 7 has no staff. M3 had a different style of sharing data with colleagues, which is not unrelated to her most educated position on the Continuum.

For Issue 15, each Manager indicated that remuneration was not important to doing the job, and this was in the anticipated direction of the E Framework. This Issue was added to the Framework after Purdy's UK findings indicated that remuneration was important for UK Ward Unit Managers (Purdy, 
1993a). We reversed the anticipated direction for the Extended Framework because of the modest level of university salaries, and this was correct.

No Manager mentioned Issue 16 that remuneration should not be related to performance. These did not follow the Extended Framework. The absence of the topic in the interviews indicates a general lack of such explicit measures in Galician universities, where a Manager would be assessed in a number of ways, but it would not be related to salary.

Managers 2, 4 and 5 conformed with the anticipated direction of the Extended Framework of Issue 17, that notions of success are important for both her ability to control affairs and her consequent self-confidence in the job. More specifically, one noted that success was important to control affairs, two others that their success increased their self-confidence in the job. This Issue was added to the Framework after Purdy's study suggested that it was important (Purdy, 1993a) and has some salience here. These three Managers, with a fourth, felt that importantly the job allowed them to manage their own self-development. Success has some relevance to some Managers, and selfdevelopment could accompany this.

With Issue 18, Managers 1,2, 3, 6 and 7 conformed with the anticipated direction of the Extended Framework that the contacts made are an important aspect of her desire to do her job. There was a variety of contacts, four mentioned contacts outside, three with staff inside and two with students. Managers 4 and 5 did not include the Issue. This Issue originated from this study and it has some importance.

Issue 19, that social prestige is an important aspect of her desire to do the job, was noted by Managers 3, 4 and 5, and is in line with the E Framework. The Issue was added by Spanish colleagues and has some salience.

\section{SUMMARY AND CONCLUSIONS}

The interactions of Spanish public sector managers with accounting data forms the empirical basis of this paper. A group of Spanish researchers wanted to understand how public sector managers were affected by the accounting systems that provided their data and how such managers used this at a point when Government policies sought to reduce cash expenditures. For this the group interviewed the managers of seven Galician Business Schools. The group found that five of the six managers with accounting education did not use the accounting data for their decisions (Gago et al., 1997a and 1997b), but finding further understandings was difficult. The group abandoned its search, when it became aware of Purdy's Framework of Issues validated with UK public sector managers (Purdy, 1993a), and then decided to apply it as a British-Spanish group.

Next, the Original Framework of Eight Issues used the findings from the UK managers and the more finely expressed Issues 5 and 6 to produce a Revised Framework of Seventeen UK Issues. 
When this was discussed with the Spanish colleagues the direction of one Issue was amended and two Issues taken from their pre-interview material were added to make an Extended Framework of 19 Spanish Issues. This means 19 Issues have been compared with the interview material.

The comparison of the interview material with the Extended Framework showed that no Manager mentioned remuneration related to job performance; this suggested no Manager was interested in this. Only one Manager covered the remaining 18 Issues and was the only person to cover the Issues of data timeliness and change in system adequacy and timeliness, whilst only three Managers covered data inadequacy, budget appreciation, success and control, and the job's social prestige. With these exceptions the Issues in the Extended Framework are relevant to these Spanish public sector managers. Interestingly, if the Revised UK Framework had been used for comparison then there would have been a very high degree of coverage.

The only Manager who covered the 18 Issues did this largely in the anticipated direction of the Extended Framework. The exceptions were training, financial awareness and constructing own budgets, for she and five others had been trained in accounting and had financial awareness and did not construct a budget. These six were not naïve in the basic sense of the Extended Framework, but this basic naivety was shown by the lawyer-trained Manager who had no accounting training or financial awareness, however, she did not construct a budget. With these exceptions the Managers who expressed views generally did so in the anticipated direction of the Extended Framework. Again if the Revised UK Framework had been used for comparison then there would have been a higher degree of coverage and conformity.

In any case, because of the nature of the Issues it is not merely a matter of coverage and conformity, even the absence of coverage of some Issues has been useful. The absence of the Issues, which were basic to the determination of a Manager's naivety relative to handling the accounting data received, indicated that Six Managers were considered naïve in various ways. Contextual material demonstrated that these six Managers did not use the data, and this lack of use was known (Gago et al., 1997a and 1997b). The analysis here of naivety in handling data received for each Manager has provided an understanding of a Manager's naivety and has generated one of the further insights that were sought at the start of this project.

Whilst producing the Revised Framework the opportunity was taken to comment in more depth about the ideas associated with it. The notion, that a manager originally can be naïve when she starts to handle data but that this can alter with experience and training so that she is educated, has been expressed here in the form of a Continuum and also diagrammatically. With this assumption it is possible to evaluate a person's position over time, moving from naïve to educated on a Continuum. These conditions are relative to the individual's context, over time, but the notions can also be used with a group 
of people, over time. Essentially seven Issues from the possible nine relevant Issues were used in the Continuum.

Here, however, the notions have been used to determine the naivety of each Manager's handling of data from the Issues covered and their direction. This indicated that one Manager was educated about the handling of data received and used the data received. The other six Managers were naïve about the handling of data received and did not use the data. The apparent relative arrangement of the seven managers on a Continuum for handling data at one point has been shown diagrammatically.

These positions on the Continuum were subsequently compared with the management style Issue of keeping data from colleagues. Any Manager with a naïve and most naïve position on the Continuum had also shared data with colleagues, whilst any less naive Manager did not. The Manager who was most educated also shared data with colleagues. These are not absolutes but are indicative relative positions all capable of alteration.

The Issues in the Extended Framework generally were well covered and often in the anticipated direction, which suggests a high degree of validation for the Framework. The findings with the Issues, which are comparable with the Original Framework, indicate a very high degree of commonality of concern with the Issues among public sector managers in both Spain and the UK. However, six of the Spanish Managers were considered naïve in their handling of the accounting data received, as compared with one new Ward Unit Manager in the UK. One Spanish Manager was considered not naïve as compared with four not naïve Ward Unit Managers in the UK (Purdy, 1993a).

The Spanish interviews were conducted completely independently of the Original Framework. The general coverage of those Issues here has corroborated not only the useful and sensitive nature of the Issues Framework but also the sensitivity of the research methods used in the original work (Purdy, 1993a). This has demonstrated that the number and type of Issues in the Original Framework were sufficient for it to become a general research instrument for examining the handling of data by recipients.

The Frameworks demonstrate the types of managers and their 'accounting data situations' at a point. Clearly contexts and individual circumstances vary and the types of analysis used here demonstrate this. The project has demonstrated also the dynamic nature of such Frameworks, where an issue can be raised and given an anticipated direction and these then form the basis of analysis for the interactions of people with accounting data. In this way it is possible to examine the changes that occur with both the individuals and the associated systems. It is a beginning to the understanding of how public sector managers use accounting data. 


\section{FUTURE RESEARCH}

Research into the interactions of individuals and accounting data using Frameworks has only just begun. It is anticipated that the Extended Framework can be used with public sector managers elsewhere in Spain as a useful tool for analysis. It may be simpler for others doing research in the UK to start with the Revised UK Framework. In future work it will be possible for researchers to add other notions to the Issues of their Framework and then conduct studies and analysis using the methods developed in Purdy (1993a) and here. The notion of self-development has arisen from the present study.

The Extended Framework could also be modified for other non-imposed, non-cash-restricted situations in the private sector, so as to analyse how such managers compare with the Framework, and what could be added to our knowledge.

Others might choose to re-consider the nature of the notions used for naivety and if these can be improved. The positions of the individuals could be allocated to the Continuum and the nature of the Continuum studied. If there were enough studies, from known contexts, that had assembled material about individuals, their naivety and the Continuum, then it should be possible to use it to make predictions. For example, anticipate how individuals will interact with financial management accounting data given some knowledge of the Issues in the Framework, or similarly how the organizational context might develop with particular individuals. This could be conducted with public sector bodies, private sector organizations or any organizations with either a hierarchical approach or non-hierarchical approach to budgeting. It will be interesting to see what differences arise.

Those who want to focus on more precise decisions could consider if there is a difference in how accounting data is used by the same manager for different decisions. Others might be interested in the nature of a manager's decisions, the context to the decisions and the distinction between the use of accounting as a means of choosing as distinct from a general influence.

There are interesting circumstances underlying these situations found in the two sets of studies conducted with a Framework. Five of the naïve Spanish Managers had received formal accounting training along with the not naïve Manager, who was the only Manager to use the data received. In the UK only one Ward Unit Manager had received formal accounting training but all were using the data. Future work could seek to ascertain more about the management functions of managers and who uses the accounting data. The study here found that some Managers were more concerned with other matters than budgets and all the Managers had an Economic Affairs Administrator working with this data, so future work could involve such people to ascertain their views and analyse these with a suitable Framework. It may be worthwhile to consider managers' views about the accounting training or accounting ideas that they were given to analyse any problems. 


\section{ACKNOWLEDGEMENTS}

Previous versions of this paper have been given at the following venues, and the authors would like to thank colleagues at these events for their supportive comments.

The Management Control Association, Fourth International Control Systems Research Conference, The University of Reading, July 1998.

New Directions in Management Accounting: Innovations in Practice and Research, European Institute for Advanced Studies in Management, Brussels, December 1998.

British Accounting Association, University of Glasgow, March 1999.

Critical Perspectives on Accounting Conference, New York University, April 1999.

European Accounting Association, University of Bordeaux, May 1999.

Irish Accounting and Finance Association, University College, Cork, May 1999.

Department of Economics, University of Reading, May 1999.

Department of Management Science, University of Alcalá de Henares, Madrid, June 1999.

Instituto Internacional de Costes, VI International Costs Congress, University of The Minho, Braga, September 1999.

The authors would like to thank Jose Antonio Gonzalo (Universidad de Alcalá de Henares) for his valuable comments and Mary Ellen Oliverio (University of Houston) for her detailed comments, discussion and subsequent exchanges, which they value.

Derek Purdy thanks The Management Control Association for a small grant to start this work. Susana Gago thanks the Spanish Ministry of Education for grants SESEC 2001-0657 and BEC 2001-3356. They also thank Maria Gee for her comments on the recent versions and the referees for their help in structuring the paper. In particular the meaningful interaction with one referee who made a number of important suggestions to bring out the authors' approach including the continuum device. They hope all this has made the work accessible so that others will be encouraged to work with this approach and to develop it. The final form and content of the paper is the sole responsibility of the authors.

\section{REFERENCES}

Argyris, C. (1952), 'The Impact of Budgets Upon People' (The School of Business and Public Administration, Cornell University, Ithaca, New York).

Bourn, A.M. (1991), Private correspondence with D.E. Purdy.

Gago, S., M-J. Domínguez, M-A. Álvarez, F. Barros, S. Buide and J-R. Canay (1997a), 'Management Information for Competitive Excellence in Public Business Schools: A Need or a Reality?', Management (September), pp. 4-14.

M-J. Domínguez Calvo, J-R. Canay Pazos, S. Buide Diaz, F. Barros Fornos, M-A. Álvarez Dominguez (1997b), 'La Mejora de la Calidad y la Reducción de Costes como Variables de Interés Estratégico en la Universidad Pública: Estudio para Facultades y Escuelas de Empresariales' ( $5{ }^{\text {th }}$ International Management Accounting Congress, Julio, Acapulco, México).

Hopwood, A.G. (1973), An Accounting System and Managerial Behaviour (Saxon House).

Kelly, G.A. (1955), The Psychology of Personal Constructs (Norton, New York). 
Otley, D. and A.J. Berry (1980), 'Control, Organization and Accounting', Accounting, Organizations and Society, Vol. 5, pp. 231-46.

Purdy, D.E. (1991a), 'Industrial Relations, Organizational Relations and Accounting', The British Accounting Review, Vol. 23, No. 1, pp. 67-79.

(1991b), 'Natural Learning in Committee B', Management Education and Development, Vol. 22, Part 1, pp. 60-70.

(1993a), 'Accounting, Controls, Change and the Perceptions of Managers: A Longitudinal Study of Ward Units in a Teaching Hospital', Financial Accountability $\mathcal{E}^{\circ}$ Management, Vol. 9, No. 1 (February), pp. 45-66.

(1993b), 'Ward Sisters and Financial Management Accounting', Financial Accountability EManagement, Vol. 9, No. 4 (November), pp. 279-96.

(1995), 'Control and the National Health Service: Some Psychology of Managing Healthcare with Budgets and Cash Limits', in A.J. Berry, J. Broadbent and D.T. Otley (eds.), Management Control: Theory, Issues and Practices (Macmillan), pp. 255-70. 